\title{
Media Culture and the Triumph of the Spectacle
}

\author{
Douglas Kellner
}

During the past decades, the culture industries have multiplied media spectacles in novel spaces and sites, and spectacle itself is becoming one of the organizing principles of the economy, polity, society, and everyday life. An Internet-based economy has been developing hi-tech spectacle as a means of promotion, reproduction, and the circulation and selling of commodities, using multi-media and increasingly sophisticated technology to dazzle consumers. Media culture proliferates ever more technologically advanced spectacles to seize audiences and augment the culture industry's power and profit. The forms of entertainment permeate news and information, and a tabloidized infotainment culture is more and more popular. Emergent multimedia that synthesize forms of radio, film, TV news and entertainment, and the mushrooming domain of cyberspace, become spectacles of technoculture, generating expanding sites of information and entertainment, while intensifying the spectacle-form of media culture.

Political and social life is also shaped more and more by media spectacle. Social and political conflicts are increasingly played out on the screens of media culture, which display spectacles like sensational murder cases, terrorist bombings, celebrity and political sex scandals, and the explosive violence of everyday life. Media culture not only takes up expanding moments of contemporary experience, but also provides ever more material for fantasy, dreaming, modeling thought and behavior, and constructing identities. Its rituals like the Olympics, World Cup, and championship sports events, or entertainment rituals like the Oscar and Emmy awards celebrate the society's dominant values and validate a society based on competition and winning.

Of course, there have been spectacles since premodern times. Classical Greece had its Olympics, thespian and poetry festivals, its public rhetorical battles, and bloody and violent wars. Ancient Rome had its public offerings of bread and circuses, its orgies, its titanic political battles, and the spectacle of Empire with parades and monuments for triumphant Caesars and their armies, extravaganzas put on display in the 2000 film Gladiator. And as Dutch cultural historian Johan Huizinga $(1986,1997)$ reminds us, medieval life too had its important moments of display and spectacle.

The Eastern world also has its spectacles. In 2003, an exhibit on "Genghis Khan and His Legacies" at the Los Angeles County Art Museum displayed how Genghis Khan used military spectacle and power to conquer large segments of what we now see as the eastern sphere of the globe and how four sons of Khan founded the Chinese Empire, what is now Russia, Iranian civilization and the area of what are now the Stans (i.e, Pakistan, Afghanistan, and so on). These Genghis Khan Empires used military spectacle to advance their power and had displays of great ceremonial tents, art works, religious festivities, and political events to put on view their power.

Indeed, globalization itself expanded through military spectacle and Empire, and premodern history involves the spectacle of the rise and fall of the Roman Empire, the expansion and diffusion of the Genghis Khan empires, the spread and triumph of Christianity and Islam, and the rise of modern nation states and Western European and then US-dominated empires. In the early modern period, Machiavelli advised his "prince" about the productive use of spectacle for government and social control, and the emperors and kings of the modern states cultivated spectacles as part of their rituals of governance and power.

Popular entertainment long had its roots in spectacle, while war, religion, sports, and other domains of public life were fertile fields for the propagation of spectacle for centuries. Yet with the development of new multimedia and 
information technologies, technospectacles have been decisively shaping the contours and trajectories of presentday societies and cultures, at least in the advanced capitalist countries, while media spectacle also becomes a defining feature of globalization in an era of terrorism and war.

In this study, I will provide an overview of the dissemination of media spectacle throughout the major domains of the economy, polity, society, culture and everyday life in the contemporary era and indicate the theoretical approach that I deploy. This requires a brief presentation of the influential analysis of spectacle by Guy Debord and the Situationist International, and how I build upon and differ from this approach, followed by an overview of contemporary spectacle culture that attempts to sketch contours of a critical theory of the contemporary moment.

\section{| Guy Debord and the Society of the Spectacle}

The concept of the "society of the spectacle" developed by French theorist Guy Debord and his comrades in the Situationist International has had major impact on a variety of contemporary theories of society and culture. [1] For Debord, spectacle "unifies and explains a great diversity of apparent phenomena" (Debord 1967: \#10). Debord's conception, first developed in the 1960s, continues to circulate through the Internet and other academic and subcultural sites today. It describes a media and consumer society, organized around the production and consumption of images, commodities, and staged events.

For Debord, spectacle constituted the overarching concept to describe the media and consumer society, including the packaging, promotion, and display of commodities and the production and effects of all media. Using the term "media spectacle," I am largely focusing on various forms of technologically-constructed media productions that are produced and disseminated through the so-called mass media, ranging from radio and television to the Internet and latest wireless gadgets. Every medium, from music to television, from news to advertising, has its multitudinous forms of spectacle, involving such things in the realm of music as the classical music spectacle, the opera spectacle, the rock spectacle, and more recently the hip hop spectacle. Spectacle forms evolve over time and multiply with new technological developments.

My main interest in Media Spectacle (Kellner 2003), however, is in the megaspectacle form whereby certain spectacles become defining phenomena and events of their era. These range from commodity spectacles such as the McDonald's or Nike spectacle to megaspectacle political extravaganzas that characterize a certain period, involving such things as the 1991 Gulf war, the O.J. Simpson trials, the Clinton sex and impeachment scandals, or the Terror War that is defining the current era.

There are therefore many levels and categories of spectacle. Megaspectacles are defined both quantitatively and qualitatively. The major media spectacles of the era dominate news, journalism, and Internet buzz, and are highlighted and framed as the key events of the age, as were, for instance, the Princess Diana wedding, death, and funeral, the extremely close 2000 election and 36 Day Battle for the White House, or the September 11 terror attacks and their violent aftermath, including, currently, the spectacle of Iraq. Megaspectacles are those phenomena of media culture which dramatize its controversies and struggles, as well as its modes of conflict resolution. They include media extravaganzas, sports events, political happenings, and those attention-grabbing occurrences that we call news--a phenomenon that itself has been subjected to the logic of spectacle and tabloidization in the era of media sensationalism, political scandal and contestation, seemingly unending cultural war, and the new phenomenon of Terror War. Megaspectacles, like the O.J. Simpson trials, the Clinton sex and impeachment scandals, or the ongoing Terror War dominate entire eras and encapsulate their basic conflicts and contradictions, while taking over media culture.

More generally, on my conception, media spectacle involves those media and artifacts that embody contemporary society's basic values and serve to enculturate individuals into its way of life (Kellner 1995, 2003). Thus, while Debord presents a rather generalized and abstract notion of spectacle, I engage specific examples of media spectacle and how they are produced, constructed, circulated, and function in the present era. As we proceed into a new millennium, the media are becoming more technologically dazzling and are playing an ever-escalating role in everyday life. Under the influence of a multimedia image culture, seductive spectacles fascinate the denizens of the media and consumer society and involve them in the semiotics of an ever-expanding world of entertainment, information, and consumption, which deeply influence thought and action. In Debord's words: "When the real world changes into simple images, simple images become real beings and effective motivations of a hypnotic behavior. The spectacle 
as a tendency to make one see the world by means of various specialized mediations (it can no longer be grasped directly), naturally finds vision to be the privileged human sense which the sense of touch was for other epochs" (\#18). According to Debord, sight, "the most abstract, the most mystified sense corresponds to the generalized abstraction of present day society” (ibid).

Experience and everyday life are thus shaped and mediated by the spectacles of media culture and the consumer society. For Debord, the spectacle is a tool of pacification and depoliticization; it is a "permanent opium war" (\#44) which stupefies social subjects and distracts them from the most urgent task of real life--recovering the full range of their human powers through creative practice. Debord's concept of the spectacle is integrally connected to the concept of separation and passivity, for in submissively consuming spectacles, one is estranged from actively producing one's life. Capitalist society separates workers from the products of their labor, art from life, and consumption from human needs and self-directing activity, as individuals inertly observe the spectacles of social life from within the privacy of their homes (\#25 and \#26). The Situationist project, by contrast, involved an overcoming of all forms of separation, in which individuals would directly produce their own life and modes of self-activity and collective practice.

The correlative to the spectacle for Debord is thus the spectator, the reactive viewer and consumer of a social system predicated on submission, conformity, and the cultivation of marketable difference. The concept of the spectacle therefore involves a distinction between passivity and activity and consumption and production, condemning lifeless consumption of spectacle as an alienation from human potentiality for creativity and imagination. The spectacular society spreads its wares mainly through the cultural mechanisms of leisure and consumption, services and entertainment, ruled by the dictates of advertising and a commercialized media culture.

This structural shift to a society of the spectacle involves a commodification of previously non-colonized sectors of social life and the extension of bureaucratic control to the realms of leisure, desire, and everyday life. Parallel to the Frankfurt School conception of a "totally administered," or "one-dimensional," society (Horkheimer and Adorno 1972; Marcuse 1964), Debord states that "The spectacle is the moment when the consumption has attained the total occupation of social life" (\#42). Here exploitation is raised to a psychological level; basic physical privation is augmented by "enriched privation" of pseudo-needs; alienation is generalized, made comfortable, and alienated consumption becomes "a duty supplementary to alienated production" (\#42).

\section{Spectacle Economy and Politics}

Since Debord's theorization of the society of the spectacle in the 1960s and 1970s, spectacle culture has expanded in every area of life. In the culture of the spectacle, commercial enterprises have to be entertaining to prosper and, as Michael J. Wolf (1999) argues, in an "entertainment economy" business and fun fuse, so that the E-factor is becoming a major aspect of business. Via the "entertainmentization" of the economy, television, film, theme parks, video games, casinos, and so forth become major sectors of the national economy. In the U.S., the entertainment industry is now a $\$ 480$ billion industry, and consumers spend more on having fun than on clothes or health care (Wolf 1999: 4).

Global media culture is increasingly dominated by giant megacorporations that combine entertainment, information, and a vast array of media and consumer products. During the 1980s and 1990s, television networks in the United States amalgamated with other major sectors of the cultural industries and corporate capital, including mergers between CBS and Westinghouse; MCA and Seagram's; Time Warner and Turner Communications; ABC, Capital Cities, and Disney; and NBC, General Electric, and Microsoft. In 1999, CBS fused with the entertainment colossus Viacom in a $\$ 38$ billion megamerger. Dwarfing all previous information/entertainment corporation combinations, Time Warner and America On-Line (AOL) proposed a \$163.4 billion amalgamation in January 2000, which was approved a year later. This union brought together two huge corporations involved in TV, film, magazines, newspapers, books, information databases, computers, and other media, suggesting a coming synthesis of media and computer culture, of entertainment and information in a new infotainment society.

The fact that "new media" Internet service provider and portal AOL was the majority shareholder in the deal seemed to point to the triumph of the up and coming online Internet culture over the old media culture. The merger itself called attention to escalating synergy among information and entertainment industries and old and new media in the form of the networked economy and cyberculture. Yet the dramatic decline in the AOL/Time Warner stock 
price and corporate battles for control of the giant corporation illustrated the tensions between old and new media and the instabilities and uncertainties at the heart of global capitalism. The return to dominance of the corporation by the Time Warner forces in 2003 seem to deflate some of the hype concerning "new media" and the "new economy" (see Kellner 2003a).

In Europe also there have been increasing mergers of media corporations, the rise and decline of media giants like Viviendi and Bertelsmann, and the ascendance of new conglomerates to take the place of declining media empires. In France, the Dassault group, headed by a rightwing politician who controlled a media empire, has taken over the weekly Express and 14 other acquisitions, while another French rightwing group headed by Jean-Luc Lagardere, an associate of Jacques Chirac is France's biggest publisher, controls the magazine market and is attempting to expand into telecommunications (Ramonet 2002). In Italy, Silvio Berlusconi owns the three main private television channels and as prime minister now also controls state television, while in Spain the Prisa company controls major newspaper and other publications, as well as radio and television networks.

These amalgamations bring together corporations involved in TV, film, magazines, newspapers, books, information data bases, computers, and other media, suggesting a coming together of media and computer culture, of entertainment and information in a new networked and multimedia infotainment society. There have also been massive mergers in the telecommunications industry, as well as between cable and satellite industries with major entertainment and corporate conglomerates. By 2002, ten gigantic multinational corporations, including AOL Time Warner, Disney-ABC, General Electric-NBC, Viacom-CBS, News Corporation, Viviendi, Sony, Bertelsmann, AT\&T, and Liberty Media, controlled most of the production of information and entertainment throughout the globe.[2] The result is less competition and diversity, and more corporate control of newspapers and journalism, television, radio, film, and other media of information and entertainment.

To succeed in the ultracompetitive global marketplace, corporations need to circulate their image and brand name so business and advertising combine in the promotion of corporations as media spectacles. Endless promotion circulates the McDonald's Golden Arches, Nike's Swoosh, or the corporate symbols of Apple, Intel, or Microsoft. In the brand wars between commodities, corporations need to make their corporate logo a familiar signpost in contemporary culture. Corporations place their defining brand images on their products, in ads, in the spaces of everyday life, and in the midst of media spectacles like important sports events, TV shows, movie product placement, and wherever they can catch consumer eyeballs to impress their brand name on a potential buyer. Consequently, advertising, marketing, public relations and promotion are an essential part of commodity spectacle in the global marketplace.

In a global media culture, celebrities are the manufactured and managed deities of the contemporary moment. Celebrities are the icons of media culture, the gods and goddesses of everyday life. To become a celebrity requires recognition as a star player in the field of media spectacle, be it sports, entertainment, business, or politics. Celebrities have their handlers and image managers to make sure that their stars continue to be seen and positively perceived by publics. Just as with corporate brand names, celebrities become products to sell their Madonna, Michael Jordan, Tom Cruise, or Jennifer Lopez commodities and brand image. In a media culture, however, celebrities are always prey to scandal and thus must have at their disposal an entire public relations apparatus to manage their spectacle fortunes, to make sure their clients not only maintain high visibility, but also keep projecting a positive image. Of course, within limits, transgressions can also sell and so media spectacle always contains celebrity dramas that attract public attention and can even define an entire period, as when the O.J. Simpson murder trials and Bill Clinton sex scandals dominated the media in the mid and late 1990s.

Indeed, contemporary politics is controlled by the logic of media spectacle. The Gulf war of 1991 was arguably the first event of the global village where the entire world watched a build-up to war and then dramatic real-time military action against Iraq after it invaded Kuwait in the summer of 1990 (see Kellner 1992). The Clinton era featured sex and impeachment spectacles and was capped by the most dramatic election spectacle in US history as $\mathrm{Al}$ Gore and George W. Bush found themselves in a dead-heat on election night, which was first leaning toward Gore, then called for Bush, and then declared "too close to call," leading to the spectacle of a 35 day recount war in Florida, in which the US Supreme Court declared the winner in a 5-4 vote that many see as illegitimate and a stolen election (Kellner 2001). The torpor of the Bush presidency was aroused by the September 11, 2001 terrorist attacks and subsequent Bush administration wars in Afghanistan and Iraq (Kellner 2003b).

In other parts of the world, media spectacle proved to be a major factor in the Spanish March 2004 election where the socialist party candidate upset the conservative party Prime Minister predicted to win an easy victory, 
when Spain and the global village experienced in horror the spectacle of a series of terrorist bombings killing around 200 people days before the election. At first, the government insisted that a Basque nationalist separatist group, ETA, was responsible, but information leaked out that the bombing actually had the signature of an Al Qaeda attack and that intelligence was pointing in this direction. The Spanish people used the Internet, cell phones and messaging, and other modes of communication to get people out for massive antigovernment demonstrations to condemn the alleged lies of the existing regime concerning the terrorism attacks while also denouncing its support of the Iraq invasion that, in the minds of many, had made Spain an Islamic terrorist target. The spectacle of a lying government, massive numbers of people demonstrating against it, and the use of alternative modes of information and communication developed a spike of support for the anti-government candidate. Millions of young people and others who had never voted went to the polls, and the spectacle emerged of a major political upset. This struck a blow against George W. Bush's Iraq occupation forces when the new Spanish Prime Minister withdrew Spanish forces after spectacles of violence and chaos demonstrated the dangers to Westerners in Iraq, who were seen as an occupying and oppressive force by much of the population.

Around the same time in Taiwan in late March 2004, another bizarre media spectacle erupted in a presidential election. A couple of days before the election, there appeared to be an assassination attempt on the Taiwan president Chen Shui-Bian, who was a vocal supporter of Taiwan independence from China and who had been behind in the polls. After a razor-thin upset victory by Chen, opposition party leaders claimed that he had faked an assassination, alleging that he had claimed before that his opponents had poisoned him in a close election, that he went to a private hospital that had allegedly been prepped to receive him and that would allow him to produce effective pictures of a wound, operation, and medical treatment. Opponents claimed that he had not gone to a public hospital closer to the shooting, a site that would make it more difficult to cover over pictures of a faked assassination.[3]

During the 2004 U.S. presidential election, media spectacle has been a major determinant of the campaign so far. Negative media coverage of the Bush administration during the 9/11 commission hearings, the Abu Ghraib scandal, and daily disasters in Iraq had created negative media images of the Bush administration that the Kerry campaign exploited to maintain a lead in most polls until the period leading up to the Republican convention in August, when Kerry was hit by a wave of negative ads in the Swift Boat Veterans for Bush attacks and the Republican convention that savaged Kerry for an entire week. Kerry regained momentum with what was considered a major victory in the first presidential debate and, as I conclude this study in early October, most polls have the candidates in a statistical dead heat. So far, the momentum of the campaign has been media driven and it remains to be seen if major media spectacles intervene to decisively tip the election one way or another, or if the nitty-gritty work of political organization and efforts to get out the vote will be decisive.

Entertainment has always been a prime field of the spectacle, but in today's infotainment society, entertainment and spectacle have entered into the domains of the economy, politics, society, and everyday life in important new ways. Building on the tradition of spectacle, contemporary forms of entertainment from television to the stage are incorporating spectacle culture into their enterprises, transforming film, television, music, drama, and other domains of culture, as well as producing spectacular forms of culture such as cyberspace, multimedia, and virtual reality.

\section{The Culture of the Spectacle}

Sports has long been a domain of the spectacle with events like the Olympics, World Series, Super Bowl, World Cup soccer, and NBA championships attracting massive audiences, while generating sky-high advertising rates. These cultural rituals celebrate society's deepest values (i.e. competition, winning, success, and money), and corporations are willing to pay top dollar to get their products associated with such events. Indeed, it appears that the logic of the commodity spectacle is inexorably permeating professional sports which can no longer be played without the accompaniment of cheerleaders, giant mascots who clown with players and spectators, and raffles, promotions, and contests that feature the products of various sponsors.

Sports stadiums themselves contain screens with electronic reproduction of the action, as well as giant advertisements for various products that rotate for maximum saturation-previewing environmental advertising in which entire urban sites are becoming scenes to boost consumption spectacles. Arenas like the United Center in Chicago, America West Arena in Phoenix, or Enron Field in Houston are named after corporate sponsors. Of course, after major corporate scandals or collapse, like the Enron spectacle, the ballparks must be renamed! 
Film has long been a fertile field of the spectacle, with "Hollywood" connoting a world of glamour, publicity, fashion, and excess. Hollywood film has exhibited grand movie palaces, spectacular openings with searchlights and camera-popping paparazzi, glamorous Oscars, and stylish hi-tech film. While epic spectacle became a dominant genre of Hollywood film from early versions of The Ten Commandments through Cleopatra and 2001 in the 1960s, contemporary film has incorporated the mechanics of spectacle into its form, style, and special effects. Films are hyped into spectacle through advertising and trailers which are ever louder, glitzier, and razzle-dazzle. Some of the most popular films of the late 1990s were spectacle films, including Titanic, Star Wars--Phantom Menace, Three Kings, and Austin Powers, a spoof of spectacle, which became one of the most successful films of summer 1999.

The 2000 Academy Awards were dominated by the spectacle Gladiator, a mediocre film whose best picture award and best acting award for Russell Crowe demonstrate the extent to which the logic of the spectacle now dominates Hollywood film. Some of the most critically acclaimed and popular films of 2001 were also hi-tech spectacle, such as Moulin Rouge, a film spectacle that itself is a delirious ode to spectacle, from cabaret and the brothel to can-can dancing, opera, musical comedy, dance, theater, popular music, and film. A postmodern pastiche of popular music styles and hits, the film used songs and music ranging from Madonna and the Beatles to Dolly Parton and Kiss.

In 2002-2004, a series of comic book hero spectacles were among the most popular films. Spiderman (2002) was one of the most popular films ever and has spawned a sequel in 2004. A cycle of films have proliferated, presenting comic book heroes like Hulk, the X-Men series, and the comic book-like Matrix Revisited, Terminator 3, and Charlie's Angels: Full Throttle. Superhero films embody fantasies of attained spectacular powers that enable the protagonists to conquer enemies and prevail in hi-tech environments. These cinematic spectacles are an expression of a culture that generates ever-more fantastic visions as technology and the society of the spectacle continue to evolve in novel and surprising, sometimes frightening, forms.

Television, from its introduction in the 1940s, has been a promoter of consumption spectacle, selling cars, fashion, home appliances, and other commodities along with consumer lifestyles and values. It is also the home of sports spectacle like the Super Bowl or World Series, political spectacles like elections (or, more recently, scandals), entertainment spectacle like the Oscars or Grammies, and its own events like breaking news or special events. Following the logic of spectacle entertainment, contemporary television exhibits more hi-tech glitter, faster and glitzier editing, computer simulations, and with cable and satellite television, a fantastic array of every conceivable type of show and genre.

TV is today a medium of spectacular programs like The X-Files or Buffy, the Vampire Slayer, and spectacles of everyday life such as MTV's The Real World and Road Rules, or the globally popular Survivor and Big Brother series. In 2002-4, there was a proliferation of competitive reality shows in the U.S. involving sex, dating, and marriage including The Bachelor and The Bachelorette, Cupid, and the short-lived Are You Hot? In these shows, men and women humiliate themselves, facing scorn and rejection, as they compete for the favors of sexual competitors and their few moments of media glory and reward. The most popular U.S. reality TV show of 2004, The Apprentice, presented the spectacle of Donald Trump, super capitalist, firing young would-be corporate executives in a harsh Darwinian competition to work for the eccentric and money and power obsessed mogul, The Donald. And Entertainment and spectacle are apotheosized in American Idol, the breakaway hit of summer 2002 that continues to be a TV ratings winner, rewarding young want-to-be entertainers who perform well-known pop songs, while humiliating those judged to be losers.

Theater is a fertile field of the spectacle and contemporary plays have exploited its dramaturgical and musical past to create current attractions for large audiences. Plays like Bring in 'Da Noise, Bring in da Funk, Smokey Joe's Cafe, Fosse, Swing!, and Contact draw on the history of music spectacle, bringing some of the most spectacular moments of the traditions of jazz, funk, blues, swing, country, rock, and other forms of pop entertainment to contemporary thespian audiences. Many of the most popular plays of recent years on a global scale have been spectacles including Les Miserables, Phantom of the Opera, Rent, The Lion King, Mama Mia, La Boheme, and The Producers, a stunningly successful musical spectacle that mocks the Nazis and show business. These theatrical spectacles are often a pastiche of previous literature, opera, film, or theater and reveal the lust for participation in cultural extravaganzas of contemporary audiences for all types of culture.

Fashion is historically a central domain of the spectacle, and today producers and models, as well as the actual products of the industry, constitute an enticing sector of media culture. Fashion designers are celebrities, such as the late Gianni Versace, whose murder by an ex-gay lover in 1997 was a major spectacle of its era. Versace brought together the worlds of fashion, design, rock, entertainment, and royalty in his fashion shows and emporia. When 
Yves Saint-Laurent retired in 2002, there was a veritable media frenzy to celebrate his contributions to fashion, which included bringing in the aesthetic and images of modern art and catering to demands of contemporary liberated women as he developed new forms of style and couture.

In fashion today, inherently a consumer spectacle, laser-light shows, top rock and pop music performers, superstar models, and endless hype publicize each new season's offerings, generating highly elaborate and spectacular clothing displays. The consumption spectacle is fundamentally interconnected with fashion that demonstrates what is in and out, hot and cold, in the buzz world of style and vogue. The stars of the entertainment industry become fashion icons and models for imitation and emulation. In a postmodern image culture, style and look become increasingly important modes of identity and presentation of the self in everyday life, and the spectacles of media culture show and tell people how to appear and behave.

Bringing the spectacle into the world of high art, the Guggenheim Museum's Thomas Krens organized a retrospective on Giorgio Armani, the Italian fashion designer. Earlier, Krens produced a Guggenheim show exhibiting motorcycles and plans to open a Guggenheim gallery in the Venetian Resort Hotel Casino in Las Vegas with a seven-story Guggenheim art museum next to it. Not to be outdone, in October 2000, the Los Angeles County Art Museum opened its largest show in history, a megaspectacle "Made in California: Art, Image and identity, 1900-2000," featuring multimedia exhibitions of everything from canonical California painting and photography to Jefferson Airplane album covers, surf boards, and a 1998 Playboy magazine with "The Babes of Baywatch" on its cover. In 2001, the Los Angeles County Art Museum announced that it would become a major spectacle itself, provisionally accepting a design by Rem Koolhaas that would create a spectacular new architectural cover for the museum complex. As described by the Los Angeles Times architectural critic, the "design is a temple for a mobile, post-industrial age.... Capped by an organic, tent-like roof, its monumental form will serve as both a vibrant public forum and a spectacular place to view art" (Dec. 7, 2001: F1).

Contemporary architecture too is ruled by the logic of the spectacle and critics have noticed how art museums are coming to trump the art collection by making the building and setting more spectacular than the collections. [4] The Frank Gehry Guggenheim Museum in Bilbao, Spain, the Richard Meier Getty Center in Los Angeles, the retrofitted power plant that became the Tate Modern in London, Tadao Ando's Pulitzer Foundation building in Saint Louis, and Frank Gehry's Disney Music Hall in Los Angeles all provide superspectacle environments to display their art works and museum fare. Major architectural projects for corporations and cities often provide postmodern spectacle whereby the glass and steel structures of high modernism are replaced by buildings and spaces adorned with signs of the consumer society and complex structures that attest to the growing power of commerce and technocapitalism.

Popular music is also colonized by the spectacle with music-video television (MTV) becoming a major purveyor of music, bringing spectacle into the core of musical production and distribution. Madonna and Michael Jackson would have never become global superstars of popular music without the spectacular production values of their music videos and concert extravaganzas. Both also performed their lives as media spectacle, generating maximum publicity and attention (not always positive!). Michael Jackson attracted attention in 2001 in a TV spectacle where he reportedly paid hundreds of thousands of dollars to digitally redo the concert footage he appeared in. Jackson had his images retooled so that he would be free of sweat and appear darker than the "real" image, in order to better blend in with his family members performing with him and to appear a cooler black who would appeal to his fans. And one cannot fully grasp the Madonna phenomenon without analyzing her marketing and publicity strategies, her exploitation of spectacle, and her ability to make herself a celebrity spectacle of the highest order (Kellner 1995).

Musical concert extravaganzas are more and more spectacular (and expensive!) and younger female pop music stars and groups such as Mariah Carey, Britney Spears, Jennifer Lopez, or Destiny's Child deploy the tools of the glamour industry and media spectacle to make themselves spectacular icons of fashion, beauty, style, and sexuality, as well as purveyors of music. Pop male singers like Ricky Martin could double as fashion models and male groups like 'N Sync use hi-tech stage shows, music videos, and PR to sell their wares. Moreover, hip-hop culture has cultivated a whole range of spectacle, ranging from musical extravaganzas, to lifestyle cultivation, to real life crime wars among its stars.

Eroticism has frequently permeated the spectacles of Western culture, and is prominently on display in Hollywood film, as well as popular forms such as burlesque, vaudeville, and pornography. Long a major component of advertising, eroticized sexuality has been used to sell every conceivable product. The spectacle of sex is also one of the staples of media culture, permeating all cultural forms and creating its own genres in pornography, one of 
media culture's highest grossing domains. In the culture of the spectacle, sex becomes shockingly exotic and diverse, through the media of porno videos, DVDs, and Internet sites that make available everything from teen-animal sex to orgies of the most extravagant sort. Technologies of cultural reproduction such as home video recorders (VCRs) and computers bring sex more readily into the private recesses of the home. And today the sex spectacle attains more and more exotic forms with multimedia and multisensory sex, as envisaged in Huxley's Brave New World, on the horizon.

The spectacle of video and computer games has been a major source of youth entertainment and industry profit. In 2001, the U.S. video game industry hit a record $\$ 9$ billion in sales and expects to do even better in the next couple of years (Los Angeles Times, Jan. 1, 2002: C1). For decades now, video and computer games have obsessed sectors of youth and provided skills needed for the hi-tech dot.com economy, as well as fighting postmodern war. These games are highly competitive, violent, and provide allegories for life under corporate capitalism and Terror War militarism. In the game Pac-Man, as in the corporate jungle, it's eat or be eaten, just as in air and ground war games it is kill or be killed. Grand Theft Auto 3 and State of Emergency were two of the most popular games in 2002, with the former involving high-speed races through urban jungles and the latter involving political riots and state repression! While some women and game producers have tried to cultivate kinder, gentler, and more intelligent gaming, the best-selling corporate games are spectacles for predatory capitalism and macho militarism and not a more peaceful, playful, and cooperative world.

The examples just provided suggest media spectacle is invading every field of experience from the economy, to culture and everyday life, to politics and war. Moreover, spectacle culture is moving into new domains of cyberspace that will help to generate future multimedia spectacle and networked infotainment societies. My studies of media spectacle strive to contribute to illuminating these developments and to developing a critical theory of the contemporary moment.

\section{| Debord and the Spectacle: A Critical Engagement}

In using the concept of spectacle, I am obviously indebted to Guy Debord's Society of the Spectacle and the ideas of the Situationist International. Acknowledging the debt, I also note that there are three major differences between my engagement of the concept of the spectacle and Debord's model. First, while Debord develops a rather totalizing and monolithic concept of the society of the spectacle, I engage specific spectacles, like McDonald's and the commodity spectacle, the Clinton sex scandals and impeachment spectacle, or the 9/11 terrorist attacks and Terror War spectacle (Kellner 2003a and 2003b).

I should also acknowledge that I am reading the production, text and effects of various media spectacles from the standpoint of U.S. society, and in an attempt to theorize contemporary U.S. society and culture, and more broadly, globalization and global culture, whereas Debord is analyzing a specific stage of capitalist society, that of the media and consumer society organized around spectacle. Moreover, Debord exhibits a French radical intellectual and neoMarxian perspective while I have specific class, race, gender, and regional standpoints and deploy a multiperspectivist model, using Frankfurt School critical theory, British cultural studies, French postmodern theory, and many other perspectives (Kellner 1995, 2003a and 2003b).

Secondly, my approach to these specific spectacles is interpretive and interrogatory. That is, I try to interrogate what major media spectacles tell us of contemporary U.S. and global society. For example, what McDonald's tells us about consumption and the consumer society, or globalization; what Michael Jordan and the Nike spectacle tells us about the sports spectacle and the intersection of sports, entertainment, advertising, and commodification in contemporary societies; what the O.J. Simpson affair tells us about race, class, celebrity, the media, sports, gender, the police and legal system and so on in the U.S. and what the obsessive focus on this event for months on end tells us about American media and consumer society.

In my studies of media spectacle, I deploy cultural studies as diagnostic critique, reading and interpreting various spectacles to see what they tell us about the present age, whereas Debord is more interested in a critique of capitalism and presenting revolutionary alternatives. The "popular" often puts on display major emotions, ideas, experiences, and conflicts of the era, as well as indicating what corporations are marketing. A critical cultural studies can thus help decipher dominant trends of the era and contribute to developing critical theories of the contemporary era (Kellner 1995 and 2003a; Best and Kellner 2001).

Thirdly, I analyze the contradictions and reversals of the spectacle, whereas Debord has a triumphant and 
hegemonic notion of the society of the spectacle, although he and his comrades sketched out various models of opposition and struggle and in fact inspired in part the rather spectacular May '68 events in France. For an example of the reversal of the spectacle, or at least its contradictions and contestation, take McDonald's. When I began my studies of media spectacle in the 1990s, McDonald's was a figure for a triumphant global capitalism. McDonald's was constantly expanding in the U.S. and globally; its profits were high; and it was taken as a paradigm of a successful American and then global capitalism. George Ritzer's book The McDonaldization of Society (1993, 1996) used McDonald's as a model to analyze contemporary production and consumption, while books like Golden Arches East (Watson et al 1997) valorized McDonald's as bringing modernity itself to vast sectors of the world like Russia and China and McDonald's was praised for its efficient production methods, its cleanliness and orderliness, and its bringing food value and fast, convenient food to the masses.

Suddenly, however, McDonald's became the poster corporation for protest in the anti-corporate globalization movement. The McDonald's corporation had sued some British Greenpeace activists who produced a pamphlet attacking McDonald's unhealthy food, its labor practices, its negative environmental impact, and called for protests and boycotts. McDonald's countered with a lawsuit and an anti-McDonald's campaign emerged with a Web-site McSpotlight that became the most accessed Web site in history; global and local protests emerged; and whenever there was an anticorporate globalization demonstration somewhere, a McDonald's was trashed. Suddenly, therefore, McDonald's expansion was halted, profits were down almost everywhere for the first time, and new McDonald's were blocked by local struggles. Moreover, in the U.S. and elsewhere, there were lawsuits for false advertising, for promoting addictive substances and junk food, and a lot of bad publicity and falling profits that continue to haunt McDonald's through the present.

Finally, I'm aware how Debord's conception of the society of the spectacle trumps my own analysis of the contradictions of the spectacle, their reversal and overturning. A Debordian could argue that despite the vicissitudes of the McDonald's spectacle, the Nike spectacle that involved attack of their labor practices, and other contradictions and contestations of spectacles within contemporary capitalist societies, nonetheless capitalism itself still exists more powerfully than ever, that the media and consumer society continue to reproduce themselves through spectacle, and that a market society thrives upon the vicissitudes of spectacle, and ups and downs of various corporations, personalities, and celebrities.

While this argument is hard to answer in the face of the continued global hegemony of capital, I think it is useful to analyze the contradictions and contestations of media spectacle within specific societies and to counter the notion that media and political spectacles are all-powerful and overwhelming. For instance, I have a study in Media Spectacle of how the U.S. Republican Party attempted to create the spectacle of the Clinton sex scandals and of impeachment backfired and Clinton survived the attempts of the Republicans to remove him from the presidency through negative media politics (Chapter 6).

There are, I believe, several reasons why Clinton survived the spectacle of the sex scandal and impeachment. British cultural studies has long affirmed an active audience that is not totally manipulated by the media and it appears that there is residual respect for the President, or was at the time, and that people did not like and resisted the attacks on President Clinton and the exposure in the national media of his personal and private life. Also, there have been culture wars in the U.S. that had been going on since the 1960s and the Republican impeachment spectacle backfired as many saw it, correctly I think, as a rightwing attack to overthrow an elected president. Hence, when Republicans attacked Clinton, liberals and others saw it as an illicit attempt to use the media to overthrow an elected president and resisted the spectacle and came to Clinton's support.

There were, to be sure, highly contradictory effects from the Clinton spectacles. The Republican assault on the President won sympathy and support for the beleaguered Clinton, but enabled the Republicans to focus attention on the failings of the president. They were also able to block his political agenda, and then to highlight negatives of the Clinton/Gore presidency in the 2000 election that made it difficult for Gore to emphasize the unparalleled peace and prosperity of the past eight years, positives that quickly turned to negatives with the highly destructive and incompetent economic and foreign policy disasters of the Bush administration.

And yet in some ways, the impeachment political spectacle backfired, proving, I would argue, that politics of the spectacle is unpredictable and that spectacles do not always succeed and manipulate the public, and may backfire. Celebrities, too, have experienced the reversal of the spectacle. Michael Jackson famously has had his ups and downs with media spectacle. After becoming one of the most successful media spectacles in history in part due to his spectacular music videos and concert extravaganzas supported by a productive publicity machine, he was accused in 
the 1990s of pedophilia and in a 2003 BBC interview that he participated in to help orchestrate a come-back made damning revelations about young boys sleeping at his ranch and was hit shortly thereafter with charges of sexual molestation of a teenage boy, a negative spectacle that could end his career (although the spectacle is unpredictable: while those that prosper from the spectacle can be destroyed by it, rebirth is also always possible in a celebrity spectacle culture).

Although most examples I've given of media spectacle are U.S.-based, and I'm interrogating the examples I know best, many of these spectacles have global impact. Moreover, the spectacle itself is becoming more and more global. For example, in summer 2003 the Harry Potter spectacle is an amazing global literary spectacle, with the bestselling books in history, a series of films, and Pottermania that just keeps expanding. Some years ago, the Princess Diana spectacle was probably the most interrogated event within global cultural studies. In spring and summer of 2003, the deadly SARS disease and fear of a global epidemic was a major spectacle in the global media, especially in the areas affected. And in summer 2003, the David Beckham spectacle became global as Beckham moved from the Manchester United football team to Real Madrid, and that summer there was a film, popular globally, Bend It Like Beckham. During the period, the Beckham and Posh spectacle was on display throughout media culture, featuring Beckman and his celebrity wife Posh, formerly one of the Spice Girls, who is allegedly a fashion maven and publicity hound. The Beckham-Posh affair combines media culture, fashion, sports and the global spectacle, although their spectacle turned tabloid in 2004 as Beckham was accused of having well-documented affairs.

In terms of global spectacle, more distressingly, the Al Qaeda global terrorism spectacle has been dominant, a topic of my book From September 11 to Terror War: The Dangers of the Bush Legacy (Kellner 2003b). The terror spectacle of Fall 2001 revealed that familiar items of everyday life like planes or mail could be transformed into instruments of spectacular terror. The Al Qaeda network hijacking of airplanes turned ordinary instruments of transportation into weapons as they crashed into the World Trade Center Towers and Pentagon on September 11, 2001. Mail became the delivery of disease, terror, and death, as the anthrax scare of Fall and Winter 2001 made ordinary letters threatening items. And rumors spread that the terror network was seeking instruments of mass destruction such as chemical, biological, and nuclear weapons to create spectacles of terror on a hitherto unforeseen scope.

During 2004, the bloody aftermath of the Bush administration invasion and occupation of Iraq produced an increasingly violent and chaotic spectacle that alienated U.S. allies, created numerous enemies, and threatened President Bush's re-election. The televising of 9/11 hearings in spring 2004, accompanied by best-selling books questioning Bush administration terrorism policy and the Iraq war, created negative spectacles of Bush administration bungling, after a period during which Bush received generally positive media presentations in the rush of patriotism after 9/11. The unfolding of the panorama of images of US prisoner abuse of Iraqis and the quest to pin responsibility on the soldiers and higher US military and political authorities that unfolded in May 2004 became one of the most intense media spectacles of contemporary journalism. Evoking universal disgust and repugnance, the images of young American soldiers humiliating Iraqis circulated with satellite-driven speed through broadcasting channels, the Internet, and print media and may stand as some of the most influential images of all time.

While the photos put on display the ubiquity of media spectacle and the powerful impact of images, their digital origins and circulation also require consideration. Upon obtaining over 1,000 digital photos shortly after the initial cycle of images was released by CBS and The New Yorker, the Washington Post commented in a display of photos on May 7, 2004 that while many of the images revealed shocking poses of prisoner abuse, many more were of mundane scenes of daily life in Iraq. Moreover, the digital archive was not the work of professional photojournalists but of young U.S. soldiers. It was as if a generation raised on the media and in possession of digital cameras and camcorders naturally documented its own life, as if one was a participant in a reality TV show or political documentary.

Although there were reports that the images were intended for use to intimidate new Iraqi prisoners and to "soften them up" for interrogation, [5] the pictures also emerged from fascination with taking pictures and the digital documentation of everyday life. They also revealed how quickly such images could leave a foreign country under U.S. military control by way of the Internet and circulate quickly around the world. The Pentagon indicated in the Senate and House Hearings on the Iraq scandal on May 6 that many, many more photos and video were in play and would probably be circulated in the days ahead.

Whereas the U.S. censored every image and word in the pool system concocted for the 1991 Gulf war and had strict guidelines and control mechanisms for the embedded reporters in the 2003 Iraq intervention, the digital age has made it ultimately impossible to hide the dark sides of the current Iraq occupation. The widespread use of digital 
cameras and the ease with which images can be shot and disseminated, including direct transmission through wireless connections, demonstrated how media spectacle could trump U.S. military control and circulate highly damaging representations of U.S. abuse of Iraqis. As Donald Rumsfeld exclaimed during the Iraq prisoner abuse hearings on May 7: "people are running around with digital cameras and taking these unbelievable photographs and then passing them off, against the law, to the media, to our surprise, when they had not even arrived in the Pentagon."

The role of media images in warfare and new role of digital spectacle was dramatized further on May 11, 2004 when gruesome imagery of American Nick Berg's beheading was released to the global media. The horrifying shots quickly circulated and made it clear that digital technology was an asymmetric tool of war that any side could use to sway public opinion and to confront the awful horrors of war. It was also becoming clear that Bush's Iraq intervention was a Horror Show that would continue to shock and awe global audiences in the foreseeable future.

Yet revelations during the same week that photos of alleged Iraqi prisoner abuse by British soldiers were fakes, and subsequent admission that they were, also reveals the fragile nature of digital imagery, that it can be altered and faked, and that it is hard to differentiate between real images and digital simulacra. Yet the sheer volume and ugliness of the images of US prisoner abuse trumped epistemological reflections upon the image and instead focused attention on the catastrophe of the Iraqi war itself and what it was doing to both the Iraqis and U.S. occupation forces. Deeply rooted racism stands behind and fuels the Iraqi prisoner abuse as soldiers and the U.S. public have widely viewed Iraqis and Arabs as less than human since the Gulf war of 1991. Arabs and Iraqis have been villains of countless Hollywood films and US TV shows, while racism toward all Arabs and Moslems intensified after the 9/11 attacks. In the first Gulf war, US soldiers went on a "turkey shoot," slaughtering hundreds of Iraqis escaping from Kuwait City near the end of the war. During the current Iraq war, U.S. snipers talk of "rats nests" of Iraqi troops and cheer when they take out the "vermin." U.S. architect for the failed Iraq invasion, Paul Wolfowitz, speaks of "snakes" and "draining the swamps" in "uncivilized parts of the world."

Such racist and dehumanizing perceptions facilitate reducing Iraqi prisoners to animals and less-than-human brutes as when the now notorious woman MP Lyndee English tied a leash around a naked Iraqi prisoner as if he was a dog, or U.S. soldiers perversely constructed stacks of naked Iraqi bodies into sexually humiliating positions as if they were a horde of animals. The image of Lyndee England pointing to an Iraqi male prisoner masturbating with one thumb up and another pointing to the Iraqi's genitals, accompanied by a grotesque leer, again points to the pornographic nature of the prisoner abuse. In another shocking image, a hooded Iraqi prisoner standing atop a box has his arms stretched out and wires attached to his fingers connected to electrical lines. The hood evokes the Ku Klux Klan and their notorious lynching, while the pose of the Iraqi with his arms spread out evokes Christ on the cross, and the monstrous and grotesque figure as a whole reminds art-sensitive viewers of Goya's sketches of the horrors of war.

Only a deeply racist mentality could imagine and engage in such attacks that put on display an unmastered racist brutality that wars seem to unfold. The pictures also elicit a brutal colonial mentality. The Washington Post noted that the cache of more than 1000 digital pictures revealed that the young troops took pictures of camels, exotic vistas of Iraq, and scenes of ordinary people, as well as the copious prisoner abuse and disgusting prison pictures. Many of the quasi-pornographic images released of the Iraqi male prisoners depicted a femininization of them, naked or in women's undergarments, and passively humiliated and emasculated. There is, of course, a long tradition of taking exotic pictures of faraway places, just as there is a tradition of documenting bloody atrocity scenes in wartime. In a digital age, these genres and impulses merged together, producing a panorama of horror that may end military careers and deflate American imperial ambitions in the Middle East for a generation.

To be sure, the pornographic overtones and participation by men and women along with the gloating and smirking faces of the US prison guards made the particular Abu Ghraib prison images especially toxic and explosive. Yet any number of other images of dead Iraqi civilians, U.S. bombing errors, brutal treatment by the U.S. forces of Iraqis, and the like could be easily documented and distributed through the world media. Part of the shock and distress of the images resulted from the sanitized view of the Iraq intervention in the U.S. corporate media. Wars are often defined in the public mind by negative images of atrocity, such as the naked young girl fleeing in Vietnam, with her body scarred by napalm, or the image of a young U.S. soldier lighting a peasant hut on fire with his cigarette lighter. Iraq, too, may be remembered by horrific images, in this case taken by the US troops themselves.

So far, it has been largely Arab media which have focused upon the unsavory aspects of the U.S. Iraq invasion and occupation, showing many bloody images of Iraqi civilian victims of U.S. military action and unflattering images of U.S. military forces and politicians. With the Pandora's Box of Iraqi Evils now opened, with the media's tendency 
toward pack journalism and the feeding frenzy of the moment, and with genuine fear and concerns about the direction of the Bush administration's Iraq invasion and occupation among broad segments of the public, there are certain to be many more disturbing images of the growing global media spectacle of U.S. misadventures in Iraq and outrage concerning the entire failed enterprise.

In a media age, images are impossible to control and a media spectacle concocted to be a triumphal display of U.S. military power can easily reverse into a spectacle of U.S. arrogance, brutality, and malfeasance. Yet if the images display the errors of US policy and can be used globally to demonstrate the abuse and torture of prisoners, and if they eventually force the U.S. to reverse its disastrous Iraq policies, they will prove to be examples of media images that changed the world.

Moreover, their widespread distribution and the impassioned debate around them could send the message that abuse and torture of prisoners is unacceptable, thus forcing governments and the military to cease and desist with actions that many people see as a violation of human rights and form of barbaric atavism. The impact of media spectacles are highly unpredictable and it is possible that the distressing circulation of images of Iraqi prisoner abuse could eventually have lasting, positive effects on international law and the treatment of prisoners.

\section{| Globalization, Technological Revolution, and the Restructuring of Capitalism}

Thus, media spectacle is always contradictory, ambiguous, and subject to reversal and flip-flops so that a political administration, corporations, and celebrities can never be sure if they will be beneficiaries or victims of the vagaries of spectacle. Behind the genesis and ascendancy of the expansion of media spectacle, the proliferating virtual spectacle of cyberspace, and an emerging virtual reality (VR) are the twin phenomena of the global restructuring of capitalism and technological revolution with the explosion of new forms of media and communication technology, computer and information technology, and, on the horizon, biotechnology. In earlier writings, I introduced a concept of technocapitalism to describe a configuration of capitalist society in which technical and scientific knowledge, computerization and automation of labor, and intelligent technology play a role in the process of production analogous to the function of human labor power, mechanization of the labor process, and machines in an earlier era of capitalism (Kellner 1989). The technological revolution and global restructuring of capital continue to generate new modes of societal organization, polity, sovereignty, forms of culture and everyday life, and types of contestation.

Thus, as developing countries move into the new millennium, its inhabitants, and others throughout the globe, find themselves in an ever-proliferating infotainment society, a globally networked economy, and an Internet technoculture. Contemporary theorists find themselves in a situation parallel to the Frankfurt School in the 1930s that theorized the emergent configurations of economy, polity, society and culture brought about by the transition from market to state monopoly capitalism. In their now classical texts, the Frankfurt School theorists analyzed the novel forms of social and economic organization, technology, and culture, including the rise of giant corporations and cartels and the capitalist state in "organized capitalism," in both its fascist or "democratic" state capitalist forms. They also engaged the culture industries and mass culture that served as new types of social control, novel forms of ideology and domination, and a potent configuration of culture and everyday life (Kellner 1989).

In terms of political economy, the emerging postindustrial form of technocapitalism is characterized by a decline of the state and increased power of the market, accompanied by the growing strength of globalized transnational corporations and governmental bodies and decreased force of the nation-state and its institutions. To paraphrase Max Horkheimer, whoever wants to talk about capitalism, must talk about globalization, and it is impossible to theorize globalization without talking about the restructuring of capitalism.

Globalization involves the flow of goods, information, culture and entertainment, people, and capital across an increasingly networked economy, society, and culture (see the documentation in Castells 1996, 1997, and 1998). Like the Internet, globalization is a complex phenomenon which involves positive and negative features, costs and benefits, an up and down side, and deep ambiguities and unintended consequences. Yet, like theories of information and communication technologies, most theories of globalization are either primarily negative, seeing it as a disaster for the human species, or as positive, bringing new products, ideas, and wealth to a global arena. As with technology, I propose a critical theory of globalization that would dialectically appraise its positive and negative features, its contradictions and ambiguities, that is sharply critical of its negative effects, skeptical of legitimating ideological discourse, but that also recognizes the centrality of the phenomenon in the present and that affirms and develops its 
positive features (see Best and Kellner 2001 and Kellner 2002).

To conclude: developing countries and the globalized world is emerging into a culture of media spectacle that constitutes a novel configuration of economy, society, politics, and everyday life. It involves new cultural forms, social relations, and modes of experience. It is producing an ever-expanding spectacle culture with its proliferating multimedia and interactive spectacles that are intensifying and expanding as wireless technologies develop. Critical social theory thus faces compelling challenges in theoretically mapping and analyzing these emergent forms of culture and society and the ways that they may contain novel forms of domination and oppression as well as potential for democratization and social justice.

\section{Endnotes}

1. Debord's Society of the Spectacle (1967) was published in translation in a pirate edition by Black and Red (Detroit) in 1970 and reprinted many times; another edition appeared in 1983 and a new translation in 1994. Thus, in the following discussion, I cite references to the numbered paragraphs of Debord's text to make it easier for those with different editions to follow my reading. The key texts of the Situationists and many interesting commentaries are found on various Web sites, producing a curious afterlife for Situationist ideas and practices. For further discussion of the Situationists, see Best and Kellner 1997, Chapter 3; see also the discussions of spectacle culture in Best and Kellner 2001 and my book Media Spectacle (Kellner 2003a), upon which I draw in this article.

2. See the charts on media mergers and concentration in Croteau and Hoynes 2001: 75ff. and in The Nation (Jan. $7,2002)$ with analysis by Mark Crispin Miller, "What's Wrong with This Picture?"

3. Throughout April 2004, there continued to be oppositional party demonstrations against the Chen Taiwan nationalist party and demands for an election recount and investigation of whether Chen staged his assassination; international experts, including Henry Lee who attained national fame in the O.J. Simpson trial, were investigating the assassination attempt; see David Pierson, "Forensic Expert Hounded for News,"
Los Angeles Times, April 190, 2004: B01. According to one report: "Even though Lee confirmed that both suffered from gunshot wounds, he pointed out the shooting was not a political assassination." See "Lien calls for merger of opposition parties," The China Post (June 13, 2004: 14). But Chen again formed a nationalist party (DPP) government, although there were challenges in the court.

4. See Nicholai Ouroussoff, "Art for Architecture's Sake," Los Angeles Times (March 31, 2002). I might note that economic downturn in the U.S. in 2003 forced postponement of the expansion of the Los Angeles County Art Museum and other spectacular architectural projects.

5. This was indeed the defense that the soldiers who took the pictures gave, claiming that they were ordered by superiors to take the photos; see, for example, Terence Neilan, "7 Charges Filed Against a Central Figure in Iraq Prison Abuse," New York Times (May 14, 2004). Subsequent stories revealed, however, that orders that enabled the systematic prisoner abuse in Iraq came from the top of the Pentagon and Bush administration; see Seymour Hersh, "The Grey Zone," The New Yorker, posted May 15, 2004 at http://www.newyorker.com/ fact/content/?040524fa_fact and John Barry, Michael Hirsh and Michael Isikoff, "The Roots of Torture," Newsweek, May 24, 2004.

\section{References}

Best, Steven and Douglas Kellner. 2001. The Postmodern Adventure. Science Technology, and Cultural Studies at the Third Millennium. New York and London: Guilford and Routledge.

Castells, Manuel. 1996, 1997, 1998. Three Volumes. The Networked Society. Malden, Mass. and Oxford UK: Blackwell. Croteau, David and Williams Hoynes. 2001. The Business of Media: Corporate Media and the Public Interest. Thousand Oaks, Cal.: Pine Forge Press.
Debord, Guy. 1967. Society of the Spectacle. Detroit: Black and Red.

Horkheimer, Max and Theodor W. Adorno. 1972. Dialectic of Enlightenment. New York: Continuum

Huizinga, Johann. 1986. Homo Ludens: A Study of the PlayElement in Culture. Boston: Beacon Press.

---. 1997. The Autumn of the Middle Ages. Chicago: University of Chicago Press. 
Kellner, Douglas. .1989. Critical Theory, Marxism, and Modernity. Cambridge and Baltimore. Polity Press and John Hopkins University Press.

----. 1995. Media Culture. London and New York: Routledge.

-.--. 2001. Grand Theft 2000. Lanham, Md.: Rowman and Littlefield.

---.. 2002. “Theorizing Globalization," Sociological Theory 20:285-305.

---. 2003a. Media Spectacle. London and New York: Routledge.

---. 2003b. From September 11 to Terror War: The Dangers of the Busy Legacy. Lanham, Md.: Rowman and Littlefield.

Marcuse, Herbert. 1964. One-Dimensional Man. Boston: Beacon Press.
Ritzer, George. 1993; revised edition 1996. The McDonaldization of Society. Thousand Oaks, Ca.: Pine Forge Press.

---. 1999. Exchanting a Disenchanted World. Revolutionizing the Means of Consumption. Thousand Oaks, Ca.: Pine Forge Press. York: The New Press.

Watson, James L. (ed) 1997. Golden Arches East: McDonald's in East Asia. Palo Alto, California: Stanford University Press.

Wolf, Michael J. 1999. Entertainment Economy: How MegaMedia Forces are Transforming Our Lives. New York: Times Books

Kellner, Douglas. .1989. Critical Theory, Marxism, and Modernity. Cambridge and Baltimore. Polity Press and John Hopkins University Press. 